\title{
Effect of Socio-Economic Factors on Adoption of Soil Conservation Measures in Kurundu Oya Sub Catchment
}

\author{
M.G.T.S. Amarasekara, N.D.K. Dayawansa ${ }^{1}$ and R. P. De Silva ${ }^{1}$ \\ Postgraduate Institute of Agriculture \\ University of Peradeniya \\ Peradeniya, Sri Lanka
}

\begin{abstract}
Human induced soil erosion continues to be a major issue in terms of crop production and river water quality of the Upper Mahaweli Catchment Area (UMCA). Although the direct causes of soil erosion are well known, the underlying root causes are embedded in socio-economic conditions in the society. Many researchers have pointed out that the problem of low adoption is associated with incompatibility of the technology with the prevailing socio-economic condition of the community. Therefore, an attempt was made to identify the constraints to adopt soil conservation measures in the study area. The study consisted of three steps including a questionnaire survey, in depth interviews and transects walks. According to the results of the study, the investment on soil conservation measures is likely to increase with the farm income, level of awareness and the ownership security of the land. It was identified that even the encroachers (people who encroached the state lands) can be mobilized towards soil conservation to a certain extent through awareness programs. The capacity of the extension service has to be strengthened in order to make the farming community aware of soil conservation. Land alienation programs could make effective changes in soil conservation by giving social values to the land owner through a more secure land tenure system.
\end{abstract}

\section{INTRODUCTION}

Human-induced soil erosion poses a great threat to sustainability of soil and water resources in the Kurundu Oya sub catchment of the Upper Mahaweli Catchment Area (UMCA). Middle and upper parts of the sub catchment are among the areas mostly affected by soil erosion (Kumarihamy and Dayawansa, 2009). Human-induced soil erosion in the UMCA was accelerated during the colonial period with the introduction of plantation agriculture. The evidence of the first attempt made to control soil erosion dates back to 1873 , when the Secretary of State ordered that, no land above 5000 feet should be alienated (Madduma Bandara, 1997). Then the Forest Ordinance (1907) was enacted by the colonial administration, mainly to restrict encroachments by peasants. The Soil Conservation Act (1951) was introduced to make provisions to acquire sensitive lands for conservation purposes, to control exploitation of forest lands and to provide assistance to owners of lands in sensitive areas. Several donor-funded projects have been implemented to address the issues of the land degradation in the UMCA during the past two to three decades. Some of these projects were Land Use Planning Projects in 1983, Upper Mahaweli Management

1 Department of Agricultural Engineering, Faculty of Agriculture, University of Peradeniya, Peradeniya, Sri Lanka 
Project in1987 and Upper Watershed Management Project in 1997. Over the years, these projects have promoted various soil conservation measures, namely, hedgerows, stone bunds, terraces and contour ditches. However, in the absence of locally available material, many of these soil conservation technologies require substantial investment of resources which are not affordable to many households. The top-down approach used to plan and implement soil conservation projects also led to keep communities away from the adoption of new technologies. Since nearly $80 \%$ of the lands are under state control, the pressure on land has been gradually developed with increasing population. Subsequently, the conflicts between the authorities and community arose because of high tendency to encroach state lands. Although the direct causes of soil erosion are well known, the underlying root causes are embedded in the socio-economic conditions of the society. Many researchers pointed out that the problem of low adoption is often not due to the technology, but rather due to the incompatibility of the technology with prevailing socio-economic conditions of the community (Aheeyar, 2000). Thus, the limited success in the adoption of soil conservation measures necessitates the investigation of the social and economic factors that influence farmers' willingness to invest on conservation measures. In this context, the study was conducted to evaluate social and economic factors that influence the adoption of soil conservation measures in the Kurundu Oya sub catchment of the UMCA. Therefore, this study was carried out to identify the constraints to the adoption of soil conservation measures in the study area, to study the association between constraints and the investment in soil conservation and to make recommendations to overcome the problems under prevailing conditions.

\section{MATERIALS AND METHODS}

\section{The study area}

The study was conducted in Kurundu oya catchment (located in between $7^{\circ} 01^{\prime}$ and $7^{\circ} 13^{\prime} \mathrm{N}$ and $80^{\circ} 48^{\prime}$ and $80^{\circ} 55^{\prime}$ E coordinates) which lies mainly in the mid and up country of Sri Lanka (Fig. 1). The total area of the catchment is approximately $76 \mathrm{~km}^{2}$, and it is situated at an altitude ranging from 250 to 2250 masl. The area is representative of potential soil erosion zones in the UMCA with respect to soil properties, landscape, farming systems and the socio-economic conditions. The area has varying slope up to $100 \%$ and medium to high mountains with narrow valley bottoms. This topographic variation has created several microclimates and soil complexes within the catchment. Major soil types according to USDA classification are Typic Rhodudults, Typic Hapludults and Typic Troporthents (Mapa et al., 2005).

\section{Data collection}

The field research consisted of three stages including both formal and informal survey methods (Chambers, 1992; Wijesuriya and Thattil, 2005). The first stage involved discussions with key informants and a group of farmers with the aim to analyze the existing situation of the adoption of soil conservation measures. The second stage consisted of a household survey using a pre-tested questionnaire. The survey was administered to collect information regarding farming systems, household characteristics and constraints in adopting soil conservation measures. The agricultural extension staff was also interviewed at this stage to obtain technical information on soil conservation. The information collected in the first two stages was confirmed by transect walks conducted at the third stage. Secondary data 
including scientific reports, paper and digital maps, and survey reports were also used as additional sources of information.



\section{Fig. 1. Location of the study area}

\section{Sampling procedure}

Since Kurundu Oya catchment is highly heterogeneous in relation to topography and the distribution of farming systems, stratified random sampling was applied to select the sample for the household survey. First, the catchment was divided into three groups according to the altitude, representing lower (below 750 masl) middle (750-1250 masl) and the upper catchment (above 1250 masl). This stratification by altitude was undertaken since soil erosion is affected in different ways with its on-site and off-site effects. The second 
stratification was done according to the farming systems available in the catchment. From the stratified sampling frame, a random sample of households was obtained in order to get a representative sample (Table 1). The household was considered as a sampling unit and the total sample size was 150 . The sample size obtained from different farming systems was decided according to the population density.

\section{Data analysis}

Cross tabulation was used to interpret the general characteristics of the selected sample. The farmers' perception on constraints in adopting soil conservation measures was analyzed by conducting a matrix ranking exercise. Six constraints were identified in the preliminary discussions with farmers and were put into the columns of the matrix. Then the farmers were asked to rank them from one to six according to the descending order of the severity. The Friedman's test was used to analyze data in the matrix. The farmers involved in the ranking exercise were considered as 'blocks' and the constraints as 'treatments' (Wijesuriya and Thattil, 2005). The analysis was done employing the statistical package, Minitab version 7, and the multiple comparison was carried out as suggested by Siegel and Castellan (1988).

Regression analysis was conducted to examine the influence of the socio-economic variables on the investment in soil conservation. Since this study was mainly focused on soil conservation, the investment in soil conservation was considered as the dependent variable. It was found that farming income is a function of crop type (TC), education level (EL) of household head and the farm size (FZ). Therefore, two regression models were fitted (Equations 1 and 2).

$\mathrm{FI}=\mathrm{f}(\mathrm{TC}, \mathrm{EL}, \mathrm{FZ})-$

$\mathrm{ISC}=\mathrm{f}(\mathrm{FI}, \mathrm{AW}, \mathrm{LT})$

Where,

$\mathrm{FI}=$ Farmer's income from farm (Rs./month),

$\mathrm{TC}=$ Types of crop, dummy ( $\mathrm{TC}=1$ for vegetables and 0 otherwise),

$\mathrm{EL}=$ Education level of the household head, dummy $(\mathrm{EL}=1$ for education above grade 8 and 0 otherwise),

$\mathrm{FZ}=$ Size of the farm $(\mathrm{Ac})$,

ISC $=$ Investment in soil conservation (Rs./acre/season),

$\mathrm{AW}=$ Awareness of soil conservation, dummy $(\mathrm{AW}=1$ for satisfactory level of awareness and 0 otherwise) and

$\mathrm{LT}=$ Land tenure, dummy (LT=1 for legally owned and 0 otherwise $)$

\section{RESULTS AND DISCUSSION}

The Kurundu Oya catchment consists of a considerable heterogeneity in geomorphology and the farming systems (Table 1). Paddy farming is the dominant land use system in the lower part of the catchment where water is available year round. Most of the arable lands in the middle catchment are kept under rotational farming system which consists of paddy in the wet season and vegetables in the dry season. Intensive vegetable farming is mainly confined to the upper catchment because of the prevailing favorable climatic conditions. Apart from that, home gardening and rain-fed farming are practiced at subsistence level all over the catchment. 
Table 1. Characteristics of the surveyed sample

\begin{tabular}{lllll}
\hline \multirow{2}{*}{$\begin{array}{l}\text { Location of the } \\
\text { catchment }\end{array}$} & Village & Farming system & \multicolumn{2}{l}{$\begin{array}{l}\text { Household Head } \\
\text { (according to gender) }\end{array}$} \\
& & & Male & Female \\
\hline Lower & Batagolla & Paddy & 22 & 8 \\
Middle & Kalaganwaththa & Home gardens & 18 & 12 \\
& & Rain-fed farming & 10 & 3 \\
& Kumbalgamuwa & Paddy -Vegetable* & 32 & 4 \\
Upper & Mahakudugala & Intensive vegetable & 34 & 7 \\
Total & & & $116(77 \%)$ & $34(23 \%)$ \\
\hline
\end{tabular}

* Paddy during Maha and vegetables during Yala.

According to the results in Table 1,77\% of the heads of households are married men while the remaining $23 \%$ are women. In general, women are involved more in regular household activities than men (Wickramasinghe, 2007). Therefore, the contribution of women to the farming and conservation activities is relatively low.

With respect to the education level, about $46 \%$ household heads have received education up to primary level, and $42 \%$ have got education up to GCE $(\mathrm{O} / \mathrm{L})$ or higher. However, $11 \%$ of the surveyed households have received no formal education. The households with higher education level adopt conservation measures better than others since they are in a better position to understand soil erosion issues and have more access to information (Amarasekara et al., 2008). Nearly $89 \%$ of household heads are below 65 years, and they belong to the working force. Twenty five per cent of the sampled farmers are below 30 years and is the most active and innovative group of the farming community. They have better understanding of soil erosion problems and are more interested in soil conservation. Income, which is primarily from farming, is a key factor that affects investment on soil conservation. Forty two per cent of the sampled farmers earn less than Rs. 2500 per month and hence they are not in a position to invest on soil conservation. Only $11 \%$ of the households earn farm income over Rs. 10000 per month (Table 2). Most of them are involved in intensive vegetable cultivation.

Table 2. Education, age and monthly income of household heads adopting different farming systems

\begin{tabular}{llllllll}
\hline $\begin{array}{l}\text { Description } \\
\text { of Household head }\end{array}$ & Paddy & $\begin{array}{l}\text { Home } \\
\text { gardens }\end{array}$ & Fainfed & $\begin{array}{l}\text { Paddy- } \\
\text { vegetable }\end{array}$ & $\begin{array}{l}\text { Intensive } \\
\text { vegetable }\end{array}$ & \\
\hline Education & No schooling & 5 & 3 & 4 & 3 & - & 11 \\
& Grade 8 & 13 & 17 & 9 & 12 & 10 & 46 \\
& GCE (O/L) & 10 & 10 & - & 11 & 15 & 35 \\
& Above (O/L) & 2 & - & - & 4 & 5 & 8 \\
\hline Age & Below 30 & 7 & 2 & - & 11 & 13 & 25 \\
& 30- 65 years & 19 & 25 & 8 & 17 & 16 & 64 \\
& Above 65 & 4 & 3 & 5 & 2 & 1 & 11 \\
\hline
\end{tabular}




\begin{tabular}{llllllll}
\hline Monthly income & Below 2500 & 12 & 22 & 13 & 6 & 3 & 42 \\
(Rs.) & $2500-10000$ & 18 & 8 & - & 19 & 17 & 47 \\
& Above 10000 & - & - & - & 5 & 10 & 11 \\
\hline
\end{tabular}

\section{Constraints to adopt soil conservation measures}

Farmers were asked to list different constraints for adopting soil conservation measures in their fields. Farmers were then asked to rank the constraints they identified in the order of their importance by assigning a score on a scale from 1 to 6 (1 for most important and 6 for least important). The results of this ranking exercise are given in Fig. 2 and the statistical comparison is shown in Table 3. According to the farmers' perception, high cost of soil conservation is the most serious constraint in adopting soil conservation measures. Nearly $42 \%$ of the sampled farmers receive an income less than Rs. 2500 per month. Gamage and Aheeyar (1998) reported that lands operated by low income groups are more susceptible to soil erosion in the UMCA. They further emphasized that lack of capital is a major factor that affects adversely in soil conservation. The second most important constraint is the lack of awareness on soil conservation. It was found in the field investigations that there are only four Agricultural Instructors for the entire catchment. The Provincial Department of Agriculture is responsible for the extension service. According to the farmers' views, their service is not adequately provided at the moment. Lack of labour and the low availability of materials were recorded as the other constraints for adopting soil conservation. Since most of the younger generation is attracted by military forces and they tend to migrate to urban areas, the availability of labour force for agriculture in the catchment has declined gradually (Anon, 2001). It creates a high demand of skilled labor and hence poor farmers find it difficult to get their services. In contrast to the common belief, land tenure was not considered as a serious constraint to adopt soil conservation measures. Though farmers often complain that practice of soil conservation measures like hedge rows disrupt farming activities, it was the least important according to the results of the ranking exercise.

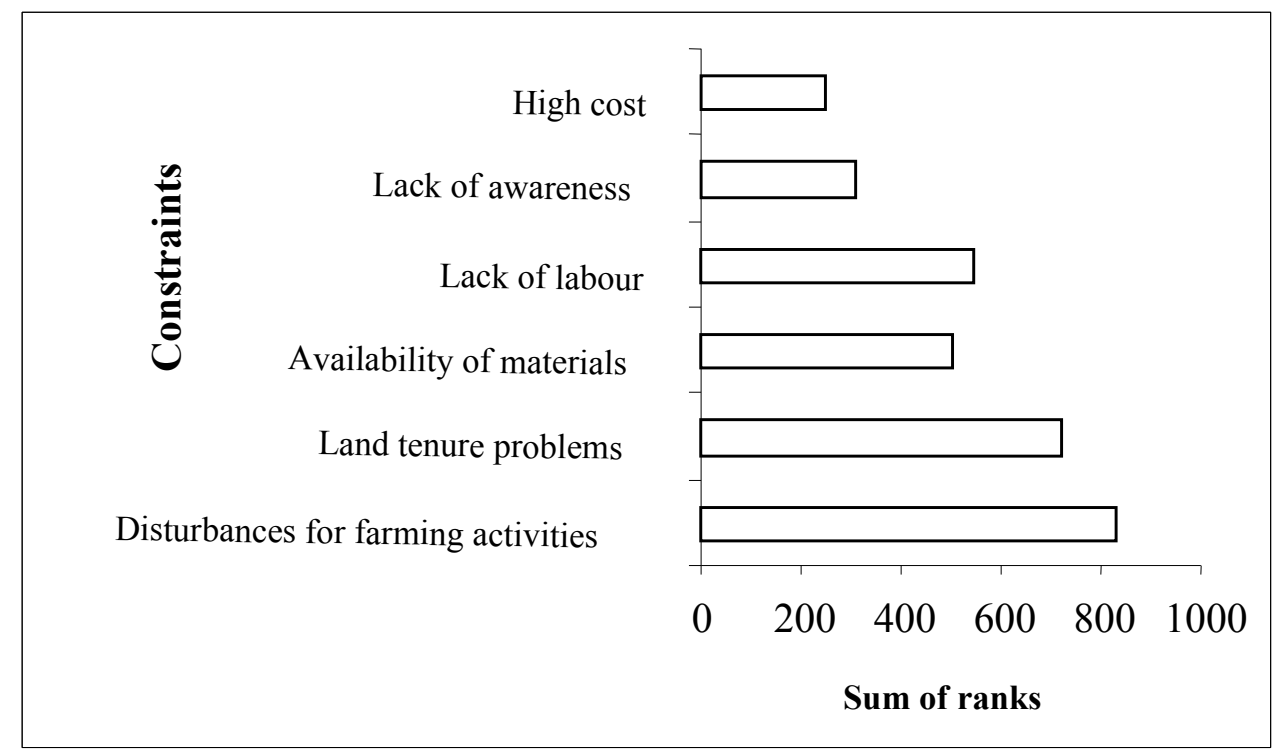

Fig. 2. Sum of ranks given by farmers for different constraints to adopt soil conservation measures $(n=150)$ 
Table 3. Statistical comparison of the ranks of constraints in practicing soil conservation measures

\begin{tabular}{lc}
\hline Constraints & Mean Score \\
\hline high cost & $1.49^{\mathrm{a}}$ \\
lack of awareness & $1.93^{\mathrm{ab}}$ \\
low availability of materials & $3.14^{\mathrm{c}}$ \\
lack of labor & $4.16^{\mathrm{d}}$ \\
land tenure problem & $5.17^{\mathrm{e}}$ \\
Disturbances for farming activities & $6.47^{\mathrm{f}}$ \\
\hline Means with same superscript are not significantly different at $\mathrm{p}=0.05$.
\end{tabular}

\section{Results of the regression analysis}

The results of the first regression model revealed that farmers' income is significantly affected by all three variables, namely crop type, education level and the farm size, included in the equation (Table 4 ). They explain $51 \%$ of the variation in farm income. The coefficients of the three variables are significant at $5 \%$ probability and have the expected signs. The results indicated that vegetable growers earn nearly Rs. 11094 more than other farmers from one acre of land in a season. Farmers having higher education level (above grade 8) earn Rs. 2889 more compared to those who have low education (below grade 8) level. In addition, when the farm size increases by one acre farmers' income increases by Rs. 3446. Crop yields and the selling prices of the farm products can significantly affect farmers' income. However, these two variables could not be assessed accurately by the household survey, because farmers were usually reluctant to maintain farm records. The results of soil analysis revealed that nutrient management of the farming systems is inappropriate. This could be a reason for low crop yields and hence low farmers' income. In addition, the influence of the middlemen in the marketing channel suppresses the bargaining power of the farmers resulting in low income from agricultural commodities.

Table 4. Regression analysis on farmer's income

\begin{tabular}{lcccc}
\hline Predictor & Coefficient & SE & t statistic & Probability \\
\hline Constant & 1128.89 & 920.53 & 1.226 & 0.222 \\
Type of crop (TC) & 11093.72 & 1284.19 & 8.639 & 0.000 \\
Education (EL) & 2889.3 & 1179.8 & 2.44 & 0.016 \\
Farm size (FZ) & 3445.93 & 864.36 & 3.98 & 0.000 \\
\hline \multicolumn{5}{l}{} \\
\hline
\end{tabular}

The results of the regression model 2 (Table 5) indicate that farm income, awareness of soil conservation practices and land tenure significantly affect the investment in soil conservation, and $75 \%$ of its variation is determined by these three variables. According to the results of regression model 2, investment in soil conservation is increased by Rs. 6 if farm income is increased by Rs. 100 per season. Thus, wealthy farmers invest more in soil conservation than the poor. Dias (2002) observed that investment in soil conservation increases by 0.26 units when farm income is increased by one unit in the Naula DS division. The report of the World Commission on Environment and Development (1987) recognizes 
poverty as one of the major factors that contributes to land degradation. Blaike (1986) describes the close association between farm income and adoption of soil conservation. Moreover, Lovejoy et al., (1986) emphasized that, farmers usually look at the soil conservation from a business perspective as they have to survive in the competitive market while struggling to meet basic needs. Therefore, the decision to adopt soil conservation practices is decided by the short-run economic gains associated with those practices.

The regression model further shows that investment on soil conservation is related to the nature of land tenure and the awareness of soil conservation practices by the household head. Though land tenure was not considered as a severe constraint for adopting soil conservation measures in the ranking exercise, a different result was found in the questionnaire survey. It was revealed that compared to the unauthorized land owners (people who have encroached state lands), farmers who own the land invest more on soil conservation measures, recorded as Rs. 2271 per acre. Many researchers point out that the land degradation is associated with insecure land tenure systems (Gunathilaka and Abeygunawardane, 1993; Gamage and Aheeyar, 1998). On the other hand, the results show that farmers with high awareness invest Rs. 2191 more on soil conservation per acre than the farmers whose awareness is poor. Gunathilaka (1990) showed that soil erosion problem is severe in farms which are operated by people who have less awareness of soil conservation.

Table 5. Regression analysis on investment in soil conservation

\begin{tabular}{lcccc}
\hline Predictor & Coefficient & SE & t statistic & Probability \\
\hline Constant & 322.4 & 158.1 & 2.03 & 0.043 \\
Awareness(AW) & 2190.6 & 93.9 & 2.33 & 0.021 \\
Land tenure(LT) & 2270.7 & 92.7 & 2.45 & 0.015 \\
Farm income(FI) & 0.06 & .005 & 18.54 & 0.000 \\
\hline \multicolumn{5}{c}{} \\
\hline
\end{tabular}

Based on the coefficients of the variables in regression equation (2) the estimated expenditure pattern on soil conservation of different farmer groups is illustrated in Fig. 3. It reveals that farmers invest Rs. 6 for soil conservation from every Rs. 100 of the farm income. Farm income is a function of many technical and socio-economic factors. As described in the regression model 1, the crop selection, education level of the household head and the farm size are some of these variables. Apart from that, soil fertility is a vital factor which determines the crop yields. However, at present, farmers obtain low yields despite the high investment on basic agricultural inputs. The main reason is nutrient imbalances in the soil due to inappropriate fertilizer management (Amarasekara et al., 2009). The soil testbased fertilizer recommendation may be a better option.

The private owners with high awareness on soil erosion invest more money compared to the other three categories. On the other hand, encroachers with low awareness invest the least amount on soil conservation. However, it is very clear that even the encroachers can be mobilized towards soil conservation through effective awareness programs. In this respect, strengthening of the extension service would contribute significantly to increase the investment in soil conservation. In addition, land alienation programs such as Jaya Bhoomi and Swarna Bhoomi would be more useful to motivate farming community for practicing soil conservation through more secure land tenure system. 


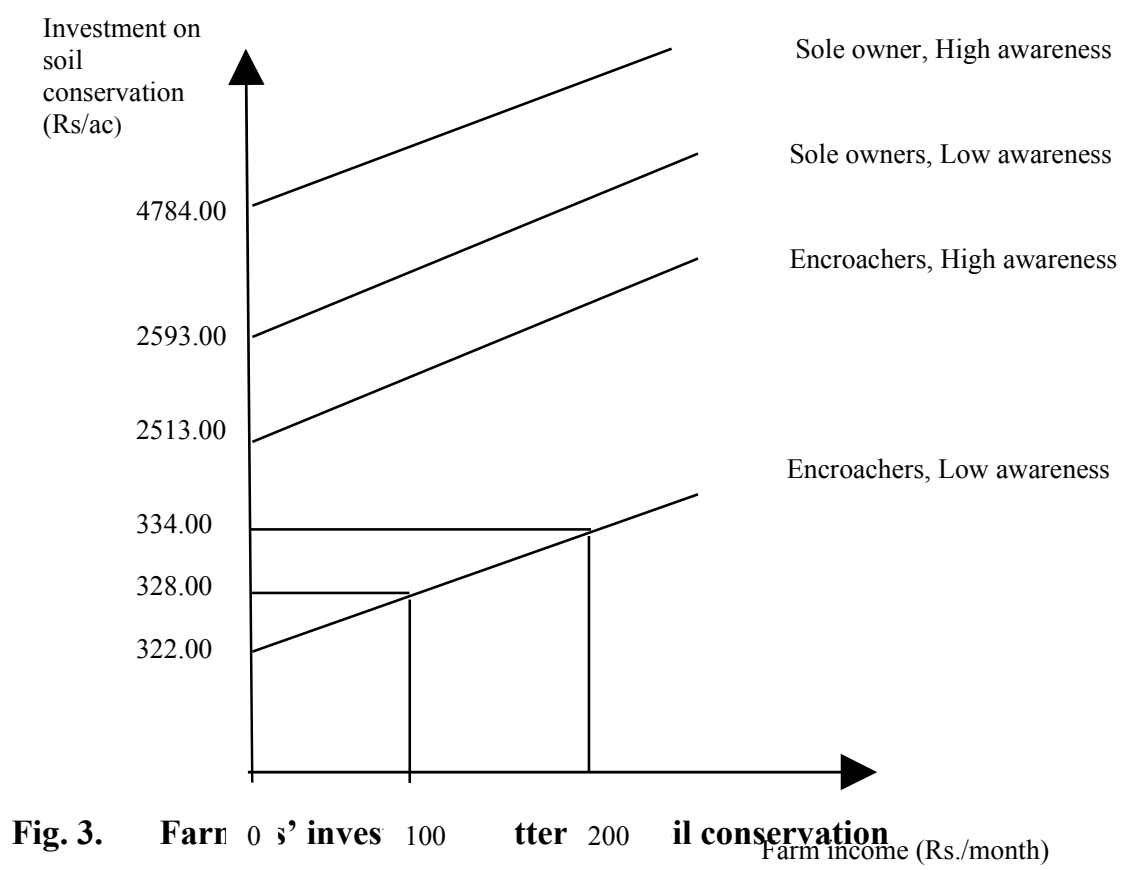

\section{CONCLUSIONS}

According to the results of this study, farmers tend to invest more on soil conservation measures with the increase of their farm income, level of awareness of soil conservation practices and the security of the land ownership. However, farm income is determined by various other technical and socio-economic factors that can be manipulated to increase the income. It was identified that even land encroachers can be mobilized towards soil conservation to a certain extent, through awareness programs. The capacity of the extension service has to be strengthened in order to make the farming community aware. Land alienation programs could make an effective change in soil conservation by giving social value to the land owner through more secure land tenure systems.

\section{ACKNOWLEDGEMENT}

The financial support given by the Crossing Boundaries Project of the PGIA, University of Peradeniya, Sri Lanka is greatly appreciated. Gratitude is also extended to Mr. A.M.K.R Bandara, Lecturer, Faculty of Agriculture, Rajarata University for giving technical support for data analysis. 


\section{REFERENCES}

Aheeyar, M.M.M., (2000). Social linkages of watershed management, Paper presented at $26^{\text {th }}$ WEDC conference at Dhaka, Bangladesh.

Anonymous, (2001). Regional land use development report, Walapane DS Division. Land Use Policy Planning Division, Nuwara-Eliya, Sri Lanka.

Amarasekara, M.G.T.S., Kumarihamy, R.M.K., Dayawansa, N.D.K. and De Silva, R.P. (2009). The impact of inappropriate soil management on river water quality: A case study in the Kurundu Oya sub catchment of Upper Mahaweli Catchment, Sri Lanka. Proceedings of the National Food and Water Conference, Colombo. Sri Lanka.

Amarasekara, M.G.T.S., Dayawansa, N.D.K., and De Silva, R.P. (2008). Participatory approach to land and water resources management in the Upper Mahaweli Catchment Area (UMCA). Symposium Proceedings of the Water Professionals' day. Geo-Informatics Society of Sri Lanka. 9-16.

Blaike, P. (1986). The Political Economy of Soil Erosion in Developing Countries, Longman, London and New York.

Chambers, R (1992). The origins and practice of participatory rural appraisal, World Development 22: 53-69.

Dias, A.A.H.A. (2002). The impact of land tenure and land degradation, The Department of National Planning, Ministry of Policy Development and Implementation. Colombo, Sri Lanka.

Forest Ordinance in Sri Lanka (1907). Ministry of Environment and Natural Resources, Sri Lanka.

Gamage, D., and Aheeyar, M. 1998. Economic and social factors affecting land degradation in UMC, Environment Action Project, Ministry of Forestry and Environment in Sri Lanka.

Gunathilaka, H.M. (1990). Institutional aspects of soil conservation and factors influencing tobacco farmers soil conservation decision in the Hanguranketha, Walapane area, Sri Lanka. Unpublished M.Sc. thesis, Agriculture University of Norway, Norway.

Gunathilaka, H.M. and Abeygunawardane P. (1993). Farm level economic analysis of soil erosion control in tobacco lands in the Hanguranketha area. Trop. Agric. Res. 5: 129-131.

Kumarihamy, R.M.K. and Dayawansa, N.D.K. (2009). Sustainable land use planning for Kurundu Oya catchment, A participatory GIS approach for integrated water resources management. Proceedings of the International Conference on Poverty, Climate Change and Water Quality, Kathmandu, Nepal.

Lovejoy, S.B., Lee, T.G. and Basley, D.B. (1986). Integration of physical and social analysis: The potential for micro targeting in conservation of soil: insight from socioeconomic research, Soil Conservation Society of America. 121-129. 
Madduma Bandara, C.M. (1997). Adverse impact of land use and improper land management practices on slope stability and landslides, Proceedings of National Symposium of Landslides, NBRO, Sri Lanka.

Mapa, R.B., Dasanayaka, A.R and Nayakakorale, H.B. (2005). Soils of the Intermediate Zone of Sri Lanka. Morphology, Characterization and Classification. Soil Science Society of Sri Lanka, 149-164.

Siegel, S and Castellan, N.J (1988). Nonparametric Statistics for Behavioral science. Mc Graw Hill, New York.

Soil Conservation Act (1951). Ministry of Agriculture Development, Sri Lanka.

WCED (1987). Our Common Future. World Commision on Environment and Development. Oxford University press.

Wickramasinghe, M. (2007) Gender Based Violence in Workplace, Monographs of Gender Based Violence in Sri Lanka, The Centre for Women's Research, Sri Lanka.

Wijesuriya, W. and Thattil, R.O. (2005). Analysis of ranking exercise in participatory rural appraisal: A case study from the smallholder rubber sector. J. of Rubber Res. Inst. Sri Lanka 87: 7-14. 